PAEDAGogia CHRISTIANA

$1 / 25$ (2010) - ISSN 1505-6872

\author{
Andrzej Bronk \\ Agnieszka Salamucha* \\ Lublin
}

\title{
Dialog jako droga do prawdy o czlowieku
}

1. W prezentowanym szkicu zajmujemy się miejscem kategorii dialogu w pedagogice, którą rozumiemy przede wszystkim jako teoretyczną refleksję nad wychowaniem. Nasz zamiar skorelowania zakresu i treści terminów dialogu i prawdy tylko na pierwszy rzut oka wydaje się łatwy. Centralne miejsce obu pojęć w tradycji filozofii europejskiej zaowocowało wielością poglądów i stanowisk oraz obszerną literatura, co zmusza do ograniczenia rozważań do niektórych tylko tematów, szczególnie tych, które mogą być interesujące dla pedagoga. Nie ma nadto potrzeby ponownego wykładania tego, co znalazło już swe naukowe opracowanie ${ }^{1}$. Skądinąd dwudziestowieczna metodologia nie poświęcała dialogowi wiele uwagi i również w słownikach filozoficznych hasło dialog nie pojawia się zbyt często².

Zgodnie z tytułowym sformułowaniem rozumiemy dialog prima facie jako czynność poznawczą. W filozofii jest on jednak również (a może przede wszystkim) rozumiany szerzej, nie tylko jako środek (narzędzie) pozyski-

${ }^{*}$ Ks. prof. dr hab. Andrzej Bronk, kierownik Katedry Metodologii Nauk KUL.

** Dr Agnieszka Salamucha, absolwentka filozofii i pedagogiki, obecnie adiunkt przy Katedrze Metodologii Nauk KUL.

1 Odsyłamy np. do analitycznie pogłębionego tekstu Stanisława Majdańskiego na temat pojęcia dyskusji: S. Majdański, O dyskusji dialogowo-opozycjonalnej. Pragmatyczno-asertywny charakter fenomenu, w: tenże, Problemy asercji zdaniowej. Szkice pragmatyczne, Lublin 1972, s. 103-158.

2 Por. Dialog (hasło zbiorowe), w: Encyklopedia katolicka, t. 3, Lublin 1979, s. 1258-1288; J. Heinrichs, Dialog, dialogisch, w: Historisches Wörterbuch der Philosophie, Bd. 2, Basel, Stuttgart 1972, szp. 226-229; W. H. Pleger, Dialog, w: H. J. Sandkühler (Hrsg.), Enzyklopädie Philosophie, Hamburg 2002, s. 255-256; M. Żardecka, Dialog, w: J. Herbut (red.), Leksykon Filozofii Klasycznej, Lublin 1997, s. 114-116. 
wania nowych prawd epistemicznych, lecz egzystencjalnie jako wyróżniony sposób istnienia (bycia) człowieka jako osoby. Rozpoczynamy od uwag ogólnych na temat dialogu (pojęcia, struktury, funkcji, typów, warunków), by aplikować je krótko do pedagogiki. Uważamy, że do dialogu pedagogicznego - jeżeli pojąć wychowanie jako dialog - odnosi się wiele z tego, co dotyczy dialogu jako takiego. Pojęciu prawdy (epistemicznej, metafizycznej, antropologicznej, aksjologicznej) poświęcamy tyle tylko uwagi, ile to potrzebne w kontekście dialogu. Ponieważ tezę o dialogu jako sposobie urzeczywistniania się człowieka w swoim człowieczeństwie podkreśla mocno filozoficzna hermeneutyka, odwołujemy się m.in. do poglądów jej czołowego przedstawiciela Hansa-Georga Gadamera.

Prezentowane przez nas metateoretyczne podejście do kategorii dialogu (i prawdy) nie jest czysto sprawozdawcze, także dlatego, że wymagałoby to większej erudycji niż ta, którą dysponujemy. Żywimy normatywnie określone preferencje co do sposobu rozumienia obu kategorii oraz ich znaczenia dla pedagogiki i praktyki wychowawczej, ale nie dajemy praktycznych rad, jak konkretnie realizować dialog pedagogiczny. Zdajemy sobie bowiem sprawę $\mathrm{z}$ tego, że czym innym jest teoria dialogu, a czym innym jego praktyka, nie dająca się wprost przełożyć na kategorie metodologiczne. Zamiary nasze, kiedy, jak metodolodzy, pytamy o miejsce kategorii dialogu w pedagogice, są skromniejsze: chcemy wskazać na niektóre problemy, jakie wiążą się z samą kategorią dialogu oraz jej aplikacją do pedagogiki.

2. Czynność dialogowania (rozmawiania) należy do najpospolitszych zjawisk międzyludzkich, związanych z faktem, że człowiek jest istotą, odznaczająca się posiadaniem języka (animal loquax) i komunikującą się językowo z innymi ludźmi.

Bezdyskusyjne jest przynajmniej to, że dyskutowanie, podobnie jak dialogowanie, należy do fenomenów najpowszechniejszych, najpospolitszych. I tak jak aktywność stwierdzania, z którą się [...] nierozerwalnie łączy, towarzyszy nieodmiennie człowiekowi w jego życiu indywidualnym i społecznym, od podstawowej struktury rodzinnej poczynając a na społecznościach międzynarodowych kończąc ${ }^{3}$.

Powszechnie przytaczana definicja człowieka jako animal rationale (zwierzę rozumne) bierze swój początek w greckiej definicji dzoon logon echon, gdzie logos oznacza nie tylko rozum i racjonalność, lecz przede wszystkim język i mówienie. Od zarania też dziejów filozofii zachodniej pojęcie dialogu (dyskursu) odgrywało rolę kluczową w bliskości z innymi

${ }^{3}$ S. Majdański, dz. cyt., s. 103-104. 
kluczowymi pojęciami poznania, rozumu, argumentacji, racji, krytyki, rozumienia, komunikowania i porozumienia. Upraszczająco wskazuje się na trzy zasadnicze podejścia do dialogu i tradycje dialogu: Sokratejsko-Platońska, traktującą go jako sposób dochodzenia do prawdy, Buberowsko-Levinasowską, upatrującą w dialogu miejsce dogłębnego spotkania z drugim człowiekiem oraz najnowszą, Gadamerowską, starającą się łączyć oba podejścia.

Starożytność grecka przypisywała dialogowi ważne znaczenie najpierw jako gatunkowi literackiemu (dramat, retoryka), potem jako argumentatywnemu sposobowi dochodzenia do prawdy, zwłaszcza o człowieku. Jako początek i podstawę myślenia dialogowego wymienia się zwykle maieutyczną metodę Sokratesa.

Znaczenie Sokratesa dla kultury europejskiej jest nie do przecenienia $\mathrm{z}$ tego głównie względu, że zapoczątkował on metodyczną procedurę organizowania pozawerbalnych warunków dialogu, wcześniej nim przystąpi się do wymiany sądów i opinii sformułowanych słownie 4 .

Pojmując zadanie filozofii jako kształcenie młodych ludzi na „dobrych mężów i dobrych obywateli”, czyli prowadzenie ich do doskonałości (,„noty”), zapewniającej również szczęśliwość, Sokrates upatrywał jej metodę $\mathrm{w}$ dialogu ${ }^{5}$, tj. żywej rozmowie z interlokutorem. Dialog stanowi jedyny sposób dochodzenia do prawdy, jej ukazywania i dowodzenia.

Sokrates rozpoczyna rozmowę $\mathrm{w}$ postawie ironicznej (eironeia); ironia ta oznacza, że nauczyciel udaje, jakoby sam w danej kwestii nic nie wiedział i oczekiwał pouczenia od swego rozmówcy. Kiedy ten, biorąc na serio «udaną skromność» [...] nauczyciela i jego pozorną bezradność niejako zdemobilizowany udziela odpowiedzi niezbyt przemyślanej, Sokrates zbija ja, okazując jej bezzasadność lub absurdalne konsekwencje; rozmówca wycofuje się, proponuje inną odpowiedź, która znowu okazuje się krucha, itd. Ten etap negatywny rozmowy to elenchos - metoda elenktyczna, polegająca na zbijaniu kolejnych argumentów rozmówcy, czy będzie nim oponent, czy uczeń. Prowadzi ona do okazania, że wszystko, co się na dany temat - np. czym jest sprawiedliwość, dobro, przyjaźn - mniej lub bardziej i powszechnie mniema i mówi, jest nie do utrzymania. Pozorna wiedza okazuje się w rzeczywistości zadufaniem pokrywającym ignorancję. Po tym etapie dekonstruktywnym zaczyna się etap konstruktywny - wspólne z rozmówcą szukanie odpowiedzi prawdziwej. Al-

${ }^{4}$ J. Mizińska, Sztuka prowadzenia sporów. Aksjologiczne przesłanki dialogu, Lublin 1993, s. 28.

${ }^{5}$ Por. Dialog als Methode, „Neue Hefte für Philosophie” 2/3 (1972). 
bowiem Sokrates, jak sam twierdzi, już bez ironii, ani w danej kwestii, ani w żadnej w ogóle kwestii «wiedzy» nie posiada. Jego wyższość nad innymi, której jest świadom [...] polega, jego zdaniem, na tym, że on jeden zdaje sobie sprawę ze swojej niewiedzy (słynne «wiem, że nic nie wiem»), podczas gdy inni swoją niewiedzę biorą za wiedzę. Toteż swoją metodę w jej części konstruktywnej Sokrates nazywał metodą maieutyczną (maieutike), czyli akuszerską: mówił o sobie, że sam nic nie wiedząc, pomaga jednak innym w rodzeniu prawdy ${ }^{6}$.

W dialogach Platona, nastawionych na poszukiwanie prawd ogólnych, dialektyka jest sztuką (techne) oglądu intelektualnego, wykraczającego poza poznanie pojęciowo-dyskursywne. Co więcej, platońska nauka o ideach jest dialektyką, czyli umiejętnością prowadzenia mądrej rozmowy i dochodzenia do poznania prawdy. Platon eksponuje nie tylko teoretyczne i praktyczne „owoce” dialogu, lecz uważa samo dialogowanie za wartość wsobną bez względu na jego rezultaty. W średniowieczu dialog przybierze postać dyskusji scholastycznej ${ }^{7}$ : racjonalnego rozważania argumentów za i przeciw pewnej tezie. Odtąd w czasach nowożytnych wiele traktatów filozoficznych będzie nosiło w tytule nazwę dialog lub dyskurs ${ }^{8}$.

W XX w. pojęcie dialogu a potem dyskursu9 stało się ważne w wielu dziedzinach wiedzy, takich jak filozofia, logika, filozofia nauk (społecznych) oraz nauki humanistyczne (językoznawstwo, nauki prawne). Poprzestając na samym wymienieniu najważniejszych kierunków, przypomnijmy centralne miejsce dialogu w psychoanalizie S. Freuda, pragmatycznej filozofii języka L. Wittgensteina, semiotycznym pragmatyzmie Ch. Peirce'a, wypracowanej przez K.-O. Apela ${ }^{10} \mathrm{w}$ ramach szkoły frankfurckiej transcendentalnej pragmatyce języka i filozofii, J. Habermasa teorii komunikacji społecznej ${ }^{11}$

${ }^{6}$ I. Krońska, Sokrates, w: tenże (red.), Stownik filozofów, Warszawa 1966, szp. 434 -442 .

${ }^{7}$ Dialog scholastyczny, zwany też dialogiem perypatetycznym, polegający na przedstawianiu autorów o odmiennych poglądach, bierze swój początek w pismach Platona i Arystotelesa, a w rozwiniętej postaci pojawia się u Cycerona.

${ }^{8}$ Przykładowo: Kartezjusza, Discours de la méthode pour bien conduire sq raison, et chercher la vérité dans les sciences (1637), Galileusza, Discorsi e dimostrazioni matematiche intorno a due nuove scienze (1638), Leibniza, Discours de Métaphysique (1686), Rousseaua, Discours sur les sciences et les arts (1750).

${ }^{9}$ Por. m.in. M. Foucault, Porzadek dyskursu. Wyktad inauguracyjny wygłoszony w College de France 2 grudnia 1970, Gdańsk 2002.

${ }^{10}$ K.-O. Apel, Diskurs und Verantwortung: das Problem des Übergangs zur postkonventionellen Moral, Frankfurt am Main 1992.

${ }^{11} \mathrm{~W}$ ujęciu Habermasa teoria dyskursu staje się ekwiwalentem teorii racjonalności: J. Habermas, Theorie des kommunikativen Handelns. I: Handlungsrationalität und gesell- 
i etyce dyskursu ${ }^{12}$, H.-G. Gadamera filozoficznej hermeneutyce, rozwijanej przez W. Kamlaha i P. Lorenzena ${ }^{13}$ logice dialogowej (konstruktywizm), językoznawczej lingwistyce dyskursu, teorii argumentacji S. E. Toulmina, Ch. Perelmana nowej retoryce (nouvelle rhétorique), strukturalizmie językoznawczym F. de Saussure'a, J. L. Austina i J. R. Searle'a teorii aktów mowy, dekonstruktywizmie J. Derridy i J.-F. Lyotarda oraz ostatnio w nieformalnej logice D. Waltona ${ }^{14}$.

Na osobną wzmiankę - z powodu wpływu na pedagogikę - zasługuje rozwijana $\mathrm{w}$ drugiej połowie XX w. personalistyczna filozofia dialogu

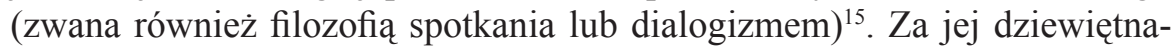
stowiecznych prekursorów uchodzą F. H. Jacobi, J. G. Fichte, W. von Humboldt i L. Feuerbach, ale za właściwych twórców filozofii dialogu (Dialogphilosophie) uważa się F. Ebnera, F. Rosenzweiga, M. Bubera, E. Levinasa, G. Marcela i R. Guardiniego. Łącząc wątki filozoficzne i teologiczne, filozofia ta podkreśla interpersonalny charakter dialogu jako miejsca spotkania osób, poszukujących sensu istnienia, swych wypowiedzi i działań. Głosi, że człowiek staje się osobą tylko dzięki relacji dialogowej lub nawet skrajnie (i enigmatycznie): nie istnieje on jako indywiduum poza relacją JA-TY ${ }^{16}$.

3. Współcześnie termin dialog odnajdujemy w swoistym znaczeniu w wielu naukach humanistycznych, zwłaszcza filozofii ${ }^{17}$, logice i teologii. Częstotliwości użycia pojęcia dialogu oraz praktyce i sztuce dyskusji ,nie współtowarzyszy jeszcze konstrukcja współmiernej teorii" ${ }^{\prime 18}$, a w definicjach dialogu, spotykanych m.in. w logice, retoryce, prakseologii, psychosocjologii czy teorii perswazji, niemało jest ogólników i retorycznych apeli.

schaftliche Rationalisierung; II: Zur Kritik der funktionalistischen Verunft, Frankfurt 1981; tenże, Erläuterungen zur Diskursethik, Frankfurt 1991.

${ }^{12} \mathrm{~J}$. Habermasa etyka dyskursu jest próbą przeformułowania Kanta idei rozumu praktycznego tak, by w wyniku racjonalnego dialogu oprzeć domniemaną uniwersalność praw moralnych na intersubiektywnej, dyskursywnej zgodzie wszystkich objętych nimi osób. „Dialog” oznacza tu rozmowę, polegającą na wzajemnej wymianie argumentów celem uzyskania obustronnego konsensusu przy poszanowaniu światopoglądowej odmienności interlokutorów.

${ }^{13}$ Według logiki dialogowej celem racjonalnego dyskursu (wnioskowania logicznego) jest uzyskanie konsensusu przez proponenta i oponenta pewnej tezy w drodze dialogowego sprawdzania racji, przytaczanych na jej rzecz oraz na argumentacyjnym kalkulowaniu ewentualnych zysków i strat. Por. P. Lorenzen, K. Lorenz, Dialogische Logik, Darmstadt 1978.

${ }^{14}$ D. Walton, Dialog Theory for Critical Argumentation, Amsterdam 2007.

${ }^{15}$ Por. Filozofia dialogu, wybrał, opracował i przedmową opatrzył B. Baran, Kraków 1991.

${ }^{16}$ Por. J. Böckenhoff, Die Begegnungsphilosophie. Ihre Geschichte - Ihre Aspekte, Freiburg, München 1970.

${ }^{17}$ Por. np. M. Szulakiewicz, Dialog i metafizyka. W poszukiwaniu nowej filozofii pierwszej, Torun 2006.

${ }^{18}$ S. Majdański, dz. cyt., s. 105. 
Wiele definicji dialogu wskazuje na rozmowę, niekiedy dyskusję (dyskurs) jako pojęcie (zjawisko) ogólniejsze, odnosząc ją do jego struktury, sposobu przeprowadzenia oraz wielorakich funkcji (celów). Stwierdzają one ogólnie (i ogólnikowo), że dialog jest: rodzajem komunikacji międzyludzkiej; miejscem wyłaniania się prawdy; sposobem poszukiwania prawdy w drodze wymiany myśli (poglądów); spotkaniem międzyludzkim; sposobem bycia, umożliwiającym istnienie wspólnoty; wymianą argumentów (racji) skierowaną na uzyskanie racjonalnego konsensusu (jednomyślności, powszechnej zgody) w drodze publicznego roztrząsania racji; sposobem załatwiania sporów w społeczeństwach demokratycznych; spotkaniem osób, chcących się porozumieć w sprawie poglądów i działan, co do których istnieją rozbieżne opinie; ujęzykowionym sposobem porozumiewania się ludzi ze sobą; rodzajem relacji międzyludzkiej, polegającej na uznaniu drugiego człowieka jako osoby (warunek udanego dialogu) przy rezygnacji z jego instrumentalizacji i narzucania siłą własnych przekonań czy wymuszania określonych sposobów zachowania/ działania; formą tworzenia i podtrzymywania wspólnoty sensu; dyskusjąjęzykową między kilkoma osobami ${ }^{19}$; rozmową, którą ktoś prowadzi sam ze sobą; myśleniem (poznaniem), które ma zawsze charakter dialogowy.

Jeżeli przyjąć przypisywany Platonowi pogląd, że myślenie jest mową wewnętrzną, milczącą rozmową umysłu ze samym sobą, dialogowaniem jest wszelkie myślenie. Chociaż dialog toczy się pierwszorzędnie między ludźmi, w sensie przenośnym mówi się także o dialogu między kulturami i światopoglądami oraz o dialogu z przeszłością a nawet przyrodą $a^{20}$.

4. W swym potocznym użyciu termin dialog ${ }^{21}$ pozostaje znaczeniowo rozmyty ${ }^{22}$. Wśród jego bliskoznaczników znajdują się m.in. takie terminy, jak: potocznie rozumiana rozmowa, konwersacja ${ }^{23}$, dyskusja ${ }^{24}$, dyskurs,

19 „Dialog jest dyskusją, prowadzoną językowo między dwoma lub więcej osobami, charakteryzującą się opozycyjnym mówieniem: w postaci pytania i odpowiedzi (celem ujaśnienia pojęć), twierdzenia i kontrtwierdzenia (celem ufundowania sądu), dowodu i jego obalania (dla ujawnienia sposobów rozumowania)". K. Lorenz, Dialog, w: J. Mittelstraß (Hg.), Enzyklopädie. Philosophie und Wissenschaftstheorie, Bd. 1, Mannheim, Wien, Zürich 1980, s. 471-472.

${ }^{20}$ Nowożytne motto (F. Bacon) głosiło, że przyroda nie odpowiada na pytania źle postawione.

${ }^{21}$ „Dialog” z greckiego diá-logos („,dwu-słowie”, „rozmowa”, łac. colloqium, sermo), dochodzenie do prawdy poprzez (dzięki) rozum i logikę; dia-legein także jako rozmawianie, przekonywanie za pomocą słów i dochodzenie do porozumienia.

${ }^{22}$ Pojęcia, które mogą oznaczać dowolne zjawiska, uważa się w nauce za pozbawione wartości poznawczej.

${ }^{23} \mathrm{~W}$ odróżnieniu od dialogu, prowadzonego z intencją uzyskania wiedzy teoretycznej lub praktycznej, w konwersacji kładzie się bardziej nacisk na momenty pozapoznawcze (estetyczne).

${ }^{24}$ „Dyskusja [...] dialog, którego uczestnicy (partycypanci), różniąc się poglądami, albo 
mowa, dogadywanie się, wymiana opinii, komunikowanie (comm-unio $\left.{ }^{25}\right)$, debata $^{26}$, porozumiewanie się, spotkanie, pertraktacja, negocjacja, paktowanie, spór, polemika, konfrontacja, walka słowna. Ustalenie ich znaczenia utrudnia niejednoznaczne użycie, nieostre pola znaczeniowe oraz częste krzyżowanie się zakresów. Przytaczane niekiedy kryteria, mające wyznaczyć pojęcie dialogu autentycznego (rzeczywistego czy udanego), odwołują się głównie do jego cech pragmatycznych, zwłaszcza do perswazyjnej skuteczności. Ze względu na znaczeniową bliskość pojęcie dialogu zastępowane bywa w filozofii, socjologii i pedagogice pojęciem dyskursu, nie mniej niejasnym i równie obciążonym historycznie. Współcześnie termin dyskurs (z łac. dis-currere - przebiegać, rozważać ${ }^{27}$ ) używany jest w kilku zasadniczych znaczeniach jako: rozmowa, tekst, język lub jego fragment i rozumowanie (argumentacja). Pojęcie dialogu wydaje się bliższe „rozumieniu” i ,,porozumieniu”, pojęcie dyskursu - ,rozumowaniu” i ,językowi”. Dlatego nie we wszystkich kontekstach „dialog” daje się zastapić „dyskursem”, jak w mówieniu o dialogu międzyreligijnym (ekumenicznym) lub międzykulturowym.

Dla potrzeb naszych rozważań przyjmujemy, że - w szerokim (potocznym) sensie dialog jest swobodną rozmową, towarzyską konwersacją, natomiast wąsko - rozmową argumentacyjną, zmierzającą do racjonalnego konsensusu, a polegająca na rozważaniu racji za i przeciw pewnej tezie. Rozumienie „dialogu” jako „rozmowy” pozwala na zamiennie używanie obu terminów. Przeciwieństwem (antonimem) dialogu jest m.in. monolog ${ }^{28}$ i milczenie, ale także siłowe narzucenie własnego stanowiska ${ }^{29}$. Przy socjologizującym podejściu do dialogu, jak w szkole frankfurckiej, miejsce racjonalnego konsensusu, uzyskanego $\mathrm{w}$ drodze argumentacji, $\mathrm{tj}$. rozumowego roztrząsania racji, zajmuje pragmatyczna (praktyczna) zgoda wszystkich zainteresowanych osób, uzyskana za pomoca procedur dyskusyjnych, przyjętych w społeczeństwach demokratycznych.

domniemując istnienie dotychczas nieujawnionych różnic w poglądach, prezentują własne stanowiska, wspierające je argumenty oraz - ewentualnie - zwalczają niezgodne $\mathrm{z}$ własnym stanowiska innych uczestników" (K. Szymanek, Sztuka argumentacji. Stownik terminologiczny, Warszawa 2001, s. 117-118).

${ }^{25}$ Komunikowanie obejmuje werbalne i pozaformalne elementy dialogu. Por. B. L. Kaczmarek, Misterne gry w komunikacje, Lublin 2005.

${ }^{26}$ Por. P. Legutko, Sztuka debaty, czyli jak się nie dać, Kraków 2009.

${ }^{27}$ H. Gronke, Diskurs, w: H. J. Sandkühler (Hrsg.), dz. cyt., s. 264-271.

${ }^{28}$ Jeśli przyjąć, że „«dialog» znaczy m.in. «przeciwstawienie monologu», «binarną relację międzyosobową» lub «bezkonfliktowy kontakt werbalny indywiduów»”(S. Majdański, dz. cyt., s. 103).

${ }_{29}$ „Stanowisko” to tyle, co pogląd, wyrażany za pomocą tezy lub wielu tez. 
Zastępując odpowiednio słowo dyskusja słowem dialog, można za S. Majdańskim ${ }^{30}$ wskazać na następujące sposoby rozumienia dialogu:

(1) typ „operacyjnego” interpersonalnego kontaktu, międzyosobowej komunikacji, społecznego dyskursu, ,,przy towarzyszącej na ogół tej wymianie werbalnej różnicy zdań, acz nie bez wykluczenia swoistej współpracy";

(2) sama dynamiczna interrelacja międzyosobowa, stan lub «międzypodstawa» napięcia - kogoś względem kogoś lub co do czegoś lub kogoś;

(3) swobodny dialog, konwersacja towarzyska oraz wszelkie formy konwersacji „regulowanej”;

(4) całość sytuacji dialogu, na którą składa się stan pewnej nieokreśloności poznawczej o charakterze zadania, pytania, problemu, sprzężony tendencją lub konkretną próbą jej przezwyciężenia;

(5) zabiegi wzajemnej interosobowej perswazji, przekonywania, nakłaniania, umacniania, nawracania, agitacji, propagandy, reklamy, sugestii itp.;

(6) niekiedy spór, zwłaszcza gdy dotyczy spraw większej wagi;

(7) aktywna postawa wobec wyrażenia, a raczej odnośnego sensu, myśli, stanu rzeczy;

(8) specjalna funkcja własności lub funkcji relatywnej wyrażenia;

(9) współroztrząsanie konkretnego twierdzenia;

(10) twórcza konfrontacja stanowisk, wymiana zdań lub opinii;

(11) obiektywna opozycja odpowiadająca kontrowersji dyskusyjnej;

(12) „skłócenie wewnętrzne jakiegoś indywiduum”.

Wśród różnych typów dialogu odróżnia się m.in.:

- ze względu na dziedzinę i zadania: dialog filozoficzny, religijny, polityczny, międzynarodowy, międzykulturowy, międzyreligijny;

- ze względu na charakter: dialog terapeutyczny (nastawiony na porozumienie i przemianę partnera dialogu), dialog prywatny (jak dialog z Bogiem) i publiczny (jak dialog społeczny Kościoła ze światem ${ }^{31}$ );

- dialog autentyczny lub pozorny w zależności od tego, czy partnerzy rzeczywiście zmierzają do porozumienia i pozostają otwarci na wzajemne argumenty, czy też (manipulacyjnie) dążą za wszelką cenę do narzucenia własnego zdania i osiaggnięcia własnej korzyści ${ }^{32}$ (jak się to dzieje w przypadku niektórych dialogów politycznych);

${ }^{30}$ S. Majdański, dz. cyt., s. 109n.

${ }^{31}$ Przykładem może być dialog ekumeniczny, jaki Kościół rzymskokatolicki toczy z innymi Kościołami chrześcijańskimi (i religiami), celem ustalania ich doktrynalnej odmienności i podobieństw.

${ }^{32}$ Przykładowo, dialog polityczny lub międzyreligijny (ekumeniczny) można uważać za nieautentyczny, gdy jedna ze stron toczy go od początku z intencją narzucenia drugiej stronie własnego stanowiska. 
- dialog partnerski, przypisujący uczestniczącym osobom takie same prawa, a więc nie dyskryminujący pod żadnym względem którejś ze stron;

- dialog manipulacyjny (różny od pozornego), w wyniku którego jedna ze stron akceptuje pewne tezy lub działania, których by nie zaakceptowała, gdyby znała całą prawdę, tzn. dysponowała pełną wiedzą m.in. o rzeczywistych motywach strony przeciwnej;

- dialog dydaktyczny i budujący, które nie służą wprost poszukiwaniu nowej prawdy, lecz upowszechnianiu i utrwalaniu pewnych poglądów.

5. Na sytuację, kiedy pewna forma komunikacji międzyludzkiej uważana jest za dialog, składa się szereg czynników:

- wspólnota dialogowa ${ }^{33}$, którą tworzą strony (uczestnicy, partnerzy) dialogu, zwane niekiedy proponentami i oponentami;

- przedmiot dialogu, którym są poglądy żywione przez strony i zajmowane przez nie stanowiska;

- sama czynność dialogowania, polegająca na wymianie argumentów (powtórzmy, że trudno mówić o dialogu tam, gdzie wypowiada się same tylko tezy);

- kontekst społeczny, kulturowy i zwłaszcza aksjologiczny wymiar dialogu, stanowiący jego tło i pozawerbalną otoczkę;

- audytorium jako wielość osób, korzystających ze swych naturalnych zdolności argumentatywnych.

Dialog toczy się zwykle przy fizycznej obecności partnerów, chociaż nie jest ona konieczna. Można go przecież prowadzić telefonicznie, listownie a dzisiaj za pomocą Internetu. Szczególnym przypadkiem dialogu jest czytanie tekstów zmarłego autora i ustosunkowywanie się do jego poglądów. Jego specyfika polega na tym, że taki autor nie może już modyfikować swych poglądów oraz ustosunkowywać do pytań i stanowiska czytelnika. Skądinąd już Platon podkreślał zalety fizycznej obecności osób dla skuteczności dialogu, gdy wypowiadaniu słów towarzyszy wzbogacający je i dointerpretywujący gest (mowa ciała) oraz dopowiadający kontekst społeczny i kulturowy.

Dialog odznacza się dialektyczną dynamiką, której wyrazem jest m.in. zamiana ról przez uczestników dialogu, kiedy występują oni jako proponenci pewnej tezy, by w odpowiedzi na argumenty oponentów zmienić się w oponentów i vice versa. Wyrazem dynamiki dialogu jest też obustronna wymiana poglądów, zasadzająca się na dialektycznej grze pytań i odpowiedzi, rodzących kolejne pytania i kontrpytania. Warunkiem udanego dialogu jest

\footnotetext{
${ }^{33}$ W terminologii Apela „wspólnota komunikacyjna” (Kommunikationsgemeinschaft).
} 
„ścieranie się" odmiennych poglądów, stanowisk, argumentów. Nie ma ich (przykładowo) w przypadku dyskusji akademickiej i budującej. Podobnie jak autentyczna rozmowa, dialog nie polega na samym wypowiadaniu poglądów, lecz na wysuwaniu argumentów za lub przeciw stawianym tezom. Istotna rola pytań polega na tym, że nie tylko dynamizują one przebieg dialogu, lecz dopiero ich dostrzeżenie pozwala na właściwe zrozumienie podtrzymywanych twierdzeń. Rozumiemy bowiem, powiada H.-G. Gadamer ${ }^{34}$, pewne twierdzenie dopiero wówczas, jeżeli znamy pytania, na które jest ono odpowiedzią. Nie jest więc dialogiem rozmowa dydaktyczna lub przesłuchiwanie świadków w procesie sądowym.

Prowadzenie rozmowy wymaga przede wszystkim, by jej partnerzy nie rozmijali się w niej. Dlatego ma ona z konieczności strukturę pytania i odpowiedzi. Pierwszym warunkiem sztuki rozmowy jest upewnienie się, czy partner nadąża ${ }^{35}$.

6. Umiejętność dialogowania (rozmawiania) uważana jest za realizację potencjalności człowieka, który spełnia się jako „zwierzę stadne” (animal social $^{36}$ ). Stwierdzany dzisiaj niekiedy zanik umiejętności prowadzenia dialogu ma swe przyczyny w szerszym kryzysie komunikacji między ludźmi. Dialog jest niezbędny wówczas, gdy istnieje rozbieżność stanowisk, które trzeba uzgodnić bez uciekania się do rozwiązań siłowych. Potrzeba dialogowania ma także swą przyczynę w omylności człowieka, szukającego korekty lub uprawomocnienia dla swych przekonań w rozmowie z innymi ludźmi ${ }^{37}$. W przypadku takich obszarów, jak sfera humanum, dialog nie tylko ułatwia poznanie, lecz zdaje się stanowić jego warunek konieczny, jeśli przyjąć (jak filozofia dialogu), że tylko w dialogu ,otwiera się prawda o człowieku". Chociaż dialog jest rodzajem sporu, nie jest nakierowany na zwalczanie przeciwnika, lecz na zrozumienie tego, co głosi oraz na porozumienie przez dostrzeżenie co najmniej tego, na czym polega odmienność stanowisk oraz jakie argumenty wysuwa się na ich rzecz. Istotna rola racji, wysuwanych na

${ }^{34} \mathrm{Za}$ Schleiermacherem Gadamer odróżnia „właściwą rozmowę”, która jest nastawiona na poszukiwanie wspólnego sensu, od „swobodnej rozmowy”, która - jak w przypadku myślenia artystycznego - służy heurystycznie stymulowaniu myśli i generowaniu nowych pomysłów. H.-G. Gadamer, Prawda i metoda, Kraków 1993, s. 191 n.

${ }^{35}$ Tamże, s. 341.

${ }^{36}$ „Dewiza homo - animal sociale zbiega się [...] z homo - animal disputabile (ta zaś dalej z homo - animal rationale lub - animal symbolicum)" (S. Majdański, dz. cyt., s. 104).

${ }^{37}$ Takie jest np. stanowisko K.-O. Apela, przypisującego dialogowi rolę metadyskursu i metakryterium prawdy, pozwalającego na rozpoznawanie racji za przyjęciem lub odrzuceniem pewnej tezy. 
poparcie tez, polega także na tym, że (powtórzmy za Gadamerem i Habermasem) rozumiemy pewną wypowiedź tylko wówczas, kiedy znamy podbudowujące ją racje. W kulturach pluralistycznych i społeczeństwach demokratycznych dialog (i następujące po nim głosowanie) jest waloryzowany jednoznacznie pozytywnie jako forma dochodzenia do konsensusu w sprawach publicznych w sytuacji istnienia rozbieżnych systemów i hierarchii wartości. Aczkolwiek, zauważmy, umożliwiając zajęcie wspólnego stanowiska, dialog niekoniecznie musi prowadzić do obiektywnie pojętej prawdy.

Przedmiotem dialogu może być każdy temat, który z pewnych powodów okazuje się interesujący i ważny dla obu stron dialogu ${ }^{38}$. Zwłaszcza w przypadku pluralistycznych społeczeństw demokratycznych, gdzie z natury rzeczy istnieją rozbieżności co do wielu istotnych zagadnień, wszystkie one są poddawane dialogowemu osądowi społeczeństwa i nie ma tu, jak pokazuje praktyka, tematów tabu. To, że można, a nawet trzeba dialogować z każdym i o wszystkim, nie oznacza, jak stwierdziliśmy, równosilni wszystkich poglądów i argumentów. Dobrze jednak, mając odmienne pomysły na urządzenie świata, umieć się porozumieć co do tego, w czym i dlaczego się różnimy.

7. Chociaż to nie wyłącznie wspólnota językowa, lecz sama rzeczywistość jest gwarancją poprawnego stosowania reguł sensu wyrażeń i akceptacji twierdzeń, intersubiektywna kontrola wypowiedzi ze strony wielu podmiotów pozwala unikać subiektywizmu i pomyłek w poznaniu. Zakładane w dialogu mocne pojęcie intersubiektywności rozumiane bywa na kilka krzyżujących się ze sobą sposobów: jako poznawcza dostępność przedmiotu (tematu) dialogu komunikującym się ze sobą podmiotom; takie uprawomocnienie pewnego twierdzenia, by mogło zostać zaakceptowane przez kompetentne w danej dziedzinie podmioty; jako możliwość posługiwania się przez wiele podmiotów wzajemnie zrozumiałym językiem o tych samych regułach sensu oraz słowami o tym samym znaczeniu (istnienie języka publicznego). Z pozorami dialogu i porozumienia (pseudokomunikacją) mamy do czynienia wówczas, kiedy strony dialogu używają materialnie wprawdzie tych samych słów, ale w różnych sensach. By zatem dialog mógł w ogóle zaistnieć, potrzebne jest pewne minimum początkowego porozumienia co do znaczenia używanych słów, chociaż, warto zauważyć, że - paradoksalnie - to właśnie dialog ma służyć jego przywróceniu.

Stwierdzenie uprzywilejowanej, bo maieutycznej funkcji dialogu (rozmowy) w dochodzeniu do prawdy oraz ujawnianiu pozawerbalnych założeń ma swe podstawy w (platońskiej) tezie, że istnieją prawdy dane ,z natury” ludziom, chociaż nie zdają sobie z nich sprawy. Nawet nie zakładając naty-

${ }^{38}$ Przykładowo, średniowieczni antydialektycy (Bernard z Clairvaux) w dyskusji z dialektykami (P. Abelard) wyjmowali spod dyskusji prawdy wiary chrześcijańskiej. 
wizmu, można utrzymywać, że dialog jest pierwotnym miejscem dokonywania się prawdy, jak czyni to m.in. H.-G. Gadamer ${ }^{39}$.

Maieutyczna produktywność sokratejskiego dialogu, jego akuszerska sztuka słowna zwraca się wprawdzie do osób będących uczestnikami rozmowy, ale dotyczy to jedynie wyrażanych przez nich opinii (Meinungen), których wewnętrzna merytoryczna konsekwencja jest rozwijana w rozmowie. W swej prawdzie ujawnia się logos, który nie jest ani mój, ani twój i który dlatego tak dalece przekracza subiektywne mniemania uczestników rozmowy, że nawet prowadzący rozmowę pozostaje niewiedzący. Dialektyka jako sztuka prowadzenia rozmowy jest zarazem sztuką wspólnego jednolitego wglądu, [...] tj. sztuką kształtowania pojęć przez opracowywanie wspólnych mniemańn ${ }^{40}$.

Ponieważ dialog toczy się dzięki tradycji złożonej w języku, jego wynik pozostaje nieprzewidywalny, gdyż nigdy nie wiadomo, dokąd zaprowadzi jego uczestników. Chociaż bowiem to ludzie ze sobą rozmawiają, biorą równocześnie udział w toczącej się przez wieki ,rozmowie idei”. Dlatego mimo istnienia praktycznych dyrektyw prowadzenia dialogu, pozostaje on bardziej sztuką niż techniką.

Wprawdzie mówimy zwykle o «prowadzeniu» rozmowy, ale im prawdziwsza rozmowa, tym mniej jej prowadzenie zależy od jej uczestników. Tak więc prawdziwa rozmowa nigdy nie przebiega tak, jak chcieliśmy ją poprowadzić. Należałoby raczej powiedzieć, że w rozmowę się wdajemy, a nawet się w nią wikłamy. Następstwo słów, zwroty w rozmowie, jej kontynuacja i konkluzja mogą być w pewien sposób sterowane, ale w tym sterowaniu partnerzy nie tyle sterują ile raczej są sterowani. Co «wyjdzie» w rozmowie, nikt z góry nie wie. Porozumienie lub jego utrata są czymś, co nam się niejako przydarza. Możemy więc później mówić, że jakaś rozmowa była udana lub że się nie powiodła. Dowodzi to, że rozmowa ma swego własnego ducha i że stosowany w niej język niesie ze sobą własną prawdę, tzn. «odkrywa» i wyzwala coś, co odtąd zaczyna istniećt1.

8. W zależności od typu dialogowi przypisuje się różne zadania ${ }^{42}$. Jeżeli dialog służy poznaniu prawdy, nazywa się go rzeczowym, jeżeli ujawnieniu własnych doświadczeń - personalnym, jeżeli spotkaniu dwu JA - egzysten-

${ }^{39}$ Wiążąc prawdę z językiem i tradycją, Gadamer odrzuca natywizm.

${ }^{40}$ H.-G. Gadamer, dz. cyt., s. 342.

${ }^{41}$ Tamże, s. 353.

${ }^{42}$ Przykładowo, J. Tarnowski stawia dialogowi w pedagogice zadanie: zrozumienia partnera, zbliżania się do niego, dzielenia się doświadczeniami oraz w miarę możności współdziałania. J. Tarnowski, Postawa dialogu w pedagogice egzystencjalno-personalnej, 
cjalnym. Zadania stawiane dialogowi mogą być realizowane równocześnie lub pojedynczo:

a) W swej funkcji społeczno-psychologicznej dialog likwiduje napięcia społeczne, sprzyjając harmonijnemu współżyciu przez dostrzeżenie i zaakceptowanie wstępnie nieprzezwyciężalnej, zasadniczej odrębności poglądów. W następstwie może służyć podejmowaniu działań na rzecz dobra wspólnego;

b) w swej funkcji komunikacyjnej dialog ułatwia porozumiewanie się między ludźmi ${ }^{43}$ przez dostrzeżenie racji teoretycznych lub praktycznych za wyborem lub odrzuceniem danego stanowiska;

c) w swej funkcji poznawczej dialog ułatwia dotarcie do prawdy epistemicznej przez odróżnianie prawdy od fałszu, stając się w ten sposób źródłem pewności poznawczej. Ponieważ dzięki dialogowi dochodzi do ujawnienia prawdy, która nie była przedtem znana żadnemu z jej uczestników, nie ma w nim zwycięzców i pokonanych. Ostatecznie zwyciężać ma nie człowiek, lecz (obiektywna) prawda, która jest celem dialogu. Niejako po drodze dialog służy klaryfikacji używanych terminów i w ten sposób ukonstytuowaniu wspólnego sensu językowego oraz usunięciu ewentualnych nieporozumień werbalnych i rzeczowych;

Dlatego mające nastąpić w rozmowie porozumienie co do danej sprawy oznacza w sposób konieczny, że dopiero w rozmowie zostanie wypracowany pewien wspólny język. Nie polega to na stosowaniu narzędzi od zewnątrz i nie można nawet powiedzieć, że to partnerzy dostosowują się do siebie; w udanej rozmowie poddają się obaj prawdzie rzeczy, która wiąże ich nowymi więzami wspólnoty. Porozumienie w rozmowie nie polega na samym tylko monologu i forsowaniu własnego stanowiska, lecz jest przemianą we wspólnotę, w której nie pozostaje się tym, czym się było ${ }^{44}$.

d) w swej funkcji egzystencjalnej, personalistycznej i aksjologicznej ${ }^{45}$ dialog, jak podkreśla to zwłaszcza filozofia spotkania ${ }^{46}$, staje się miejscem doświadczania drugiego człowieka, który staje się źródłem prawdy o nas samych oraz sposobem identyfikacji i ubogacenia własnego JA. Ujawniając

w: B. Śliwerski (red.), Pedagogika alternatywna. Dylematy teorii, t. 1, Łódź, Kraków 2000, s. 81-89.

${ }^{43} \mathrm{~W}$ swym rdzeniu termin «porozumiewać» ma zarówno „rozum” jak i „rozumienie”.

${ }^{44}$ H.-G. Gadamer, dz. cyt., s. 351.

${ }^{45}$ Szczególną uwagę aksjologicznemu wymiarowi dialogu społecznego i politycznego poświęca J. Mizińska w cytowanym powyżej dziele.

${ }^{46}$ Interpersonalna relacja JA-TY uważana jest w filozofii dialogu za zasadę myślenia filozoficznego. 
prawdę o człowieku, daną w spotkaniu osób, służy równocześnie obronie wartości ogólnoludzkich i godności człowieka.

9. Tym, co m.in. nadaje dialogowi jedność, jest wspólny przedmiot dyskusji. Podejmowanie wielu tematów grozi nieporozumieniami z braku dostatecznej kontroli nad przebiegiem dialogu. Dialog wymaga wstępnego ustalenia podzielanych poglądów i wartości, bo dopiero na ich tle można dostrzec faktyczne - teoretyczne lub praktyczne - różnice między stanowiskami stron. Zakłada też minimum porozumienia co do sposobu pojmowania kluczowych słów. Na skutek braku elementarnego porozumienia dialog przeradza się w „rozmowę głuchych” lub w spór czysto słowny. Dlatego jest niemożliwy tam, gdzie rozpadły się wszelkie więzi społeczne i przestała istnieć jakakolwiek wspólnota komunikacyjna. $Z$ drugiej strony trudno mówić o rzeczywistym dialogu w przypadku środowisk (świato-)poglądowo monolitycznych, gdzie nie ma opozycyjnych stanowisk. Aby autentyczny dialog miał miejsce, muszą istnieć sprzeczne stanowiska a jego uczestnicy poszukiwać najlepszych argumentów na obronę własnych poglądów, równocześnie dążąc do wypracowania wspólnego stanowiska i języka. Z pozorami dialogu mamy więc do czynienia tam, gdzie partnerzy od początku dzielą te same poglądy, rozprawiając (prywatnie lub publicznie) tylko po to, by utwierdzić siebie lub innych co do słuszności własnego stanowiska.

Dialog zakłada równość jego uczestników, gdyż liczą się co najwyżej rzeczowe racje i „siła” argumentów. Równość ta ma u swych podstaw tezę, że wszystkim ludziom przysługuje ta sama godność ontyczna. Dialog utrudnia postawa fundamentalistyczna, kiedy jedna ze stron, przekonana, że dysponuje „całą i wyłączną prawdą”, wykłada ją z pozycji siły (władzy), próbując dogmatycznie narzucić własną prawdę stronie przeciwnej ${ }^{47}$. Wówczas „dialog” sprowadza się co najwyżej do jednostronnego przekonywania do własnych poglądów i racji. Podstawowym warunkiem dialogu jest więc swoboda w prezentowaniu własnego stanowiska z jednej strony oraz otwartość na argumenty oponenta $\mathrm{z}$ drugiej strony.

Każde rzetelne pytanie wymaga [...] otwartości. Gdy mu jej brak, to jest ono $\mathrm{w}$ istocie pytaniem pozornym, pozbawionym rzetelnego sensu. Spotykamy coś takiego w pytaniu pedagogicznym (dydaktycznym, AB), którego swoista trudność i paradoksalność polega na tym, że jest ono pytaniem bez rzeczywiście pytającego ${ }^{48}$.

${ }^{47}$ „Nie potrafi w ogóle pytać ten, kto uważa, że wszystko wie lepiej” (H.-G. Gadamer, dz. cyt., s. 338).

${ }^{48}$ Tamże, s. 338. 
Uznanie praw strony przeciwnej do posiadania i wyrażania własnych poglądów wymaga życzliwego traktowania tego, co ma do powiedzenia, nawet jeżeli z pewnych powodów uważa się jej poglądy za fałszywe. Zasada dobrej woli (charity principle) ${ }^{49}$ wymaga, by wsłuchiwać się w sens słów $\mathrm{i}$ tezy strony przeciwnej z intencją zrozumienia, dostrzegając to, co w nich prawdziwe i dobrze uprawomocnione. Wyrazem życzliwego zainteresowania poglądami partnera dialogu jest m.in. unikanie tzw. pytań podchwytliwych a stawianie problemów, które służą dojściu do tez prawdziwych.

Dialektyka polega na tym, że nie tyle usiłujemy uchwycić słabość czegoś wypowiedzianego, ile właśnie wydobywamy prawdziwą siłę tego czegoś. Nie chodzi więc o taką sztukę argumentowania i wymowy, która nawet słabą rzecz potrafi uczynić mocną, lecz o sztukę myślenia, która coś wypowiedzianego potrafi wzmocnić na podstawie samej rzeczy ${ }^{50}$.

10. Czy (każdy) dialog jest zagrożony relatywizmem? Czy podejmuje go tylko ten, kto nie jest przekonany o własnej prawdzie i racjach? W dialog można wchodzić zarówno z pozycji siły, tzn. z przekonaniem, że zna się prawdę, którą chce się proponować innym, jak i z pozycji słabości, tzn. wątpienia we własną prawdę i dialogowego poszukiwania nowej prawdy. Tak więc podejmowanie dialogu nie musi być w każdym przypadku wyrazem niewiary we własne przekonania, podobnie jak nie oznacza gotowości do łatwej rezygnacji z własnych poglądów w każdej sytuacji. Skądinąd jednak należy się liczyć z możliwością, że podejmując dialog, zostanie się zmuszonym do zmiany wcześniejszego stanowiska, ale przecież taka jest właśnie logika dialogu.

Otwartość na prawdę partnera nie oznacza prostej akceptacji wszystkiego, co on głosi, gdyż celem dialogu jest znalezienie wspólnej prawdy, która pojawi się - być może - w wyniku dialogu. Jeżeli dialog prowadzą przeciwnicy (ideologiczni' ${ }^{51}$, polityczni, religijni, filozoficzni, naukowi, światopoglądowi), występują tu jako partnerzy, których łączy pragnienie dotarcia do prawdy (logosu), która nie jest własnością żadnej ze stron dialogu prawdy oraz o ustalenie płaszczyzny porozumienia. Ostatecznie to nie tyle same racjonalne argumenty, ile przymus płynący z prawdy i sama rzeczywistość zmuszają do akceptacji lub porzucenia wcześniejszych przekonań.

\footnotetext{
49 „Dobra wola” nie jest pojęciem operacyjnym, dlatego łatwo zarzucić drugiemu jej brak.

${ }^{50}$ H.-G. Gadamer, dz. cyt., s. 342.

${ }^{51} \mathrm{O}$ terminie ideologia, doprecyzowując jego zakres i treść, pisze m.in. J. Herbut, Ideologia a doktryna religijna, w: tenże, Artykuly i szkice. Z metodologii i teorii metafizyki, filozoficznej analizy jezzyka religii oraz etyki i metaetyki, Opole 2008, s. 261-277.
} 
Prowadzenie rozmowy oznacza podporządkowanie się sprawie, na której rozmówcy się skupiają. Prowadzenie rozmowy wymaga, by nie dążyć do przekonania innego w sporze, lecz by rzeczywiście uwzględnić rzeczową wagę odmiennego poglądu ${ }^{52}$.

11. Zadaniem dialogu jest ukonstytuowanie lub przywrócenie porozumienia odnośnie do sensu wypowiedzi językowych ${ }^{53}$ i/lub akceptowanych twierdzeń. Gdy istnieją podziały, nie dające się prima facie przezwyciężyć, dialog jest środkiem do stworzenia wspólnego języka. Równocześnie do istoty dialogu poniekąd należy jego nigdy nie zakończony charakter i to, że trud dialogowania trzeba stale podejmować na nowo. Doskonała wspólnota dialogująca jest utopią, chociaż jej stworzenie pozostaje słusznym celem dialogu ${ }^{54}$. Nie każdy dialog, prowadzony z intencją dotarcia do prawdy, osiąga swój cel, chociaż jego osiagnięcie w wielu przypadkach jest ułatwione, np. przez zrozumienie powodów, dla których każda ze stron pozostaje przy swoich poglądach i ,dobrych” racjach. Dostrzeżenie, kto i dlaczego ma rację, jest ważnym rezultatem dialogu, podobnie jak zrozumienie, dlaczego jedna ze stron używa słów w innym znaczeniu niż druga. Wypracowanie wspólnego języka przez nadanie tego samego sensu tym samym słowom pozostaje ważnym celem dialogu ${ }^{55}$. Udany dialog sprawia, że jego uczestnicy wychodzą z niego zmienieni oraz bogatsi o prawdę o sobie samych i świecie. Nie zawsze jednak kończy się on przyjęciem wspólnego stanowiska także dlatego, że ułomne poznanie ludzkie jest zawsze tylko „,w drodze do prawdy". Skądinąd obiektywna, bo intersubiektywna, tj. przekraczająca subiektywne mniemania poszczególnych uczestników dialogu, prawda nie jest nigdy pozaczasowa i definitywna. I jeśli każdy dialog się kończy, dzieje się tak zwykle w wyniku wspólnej decyzji uczestników lub kogoś, dysponującego aktualnie władzą uprawniającą do jego zakończenia.

W społeczeństwach demokratycznych dialog łączy ludzi, prowadząc do konsensusu w sprawach o witalnym znaczeniu dla funkcjonowania całego społeczeństwa. Granice dialogu ujawniają się wtedy, gdy jedna ze stron występuje autorytarnie z pozycji siły lub władzy, przedstawiając swoją prawdę

\footnotetext{
${ }^{52}$ H.-G. Gadamer, dz. cyt., s. 341.

${ }^{53} \mathrm{~J}$. Habermas rozciąga pojęcie sensowności również na ludzkie zachowania i działania.

${ }^{54} \mathrm{Na}$ napięcie między realną i idealną wspólnotą komunikacyjną zwraca uwagę m.in. K.-O. Apel. Chociaż napięcia tego nie da się, jego zdaniem, nigdy do końca zlikwidować, to dopiero perspektywa idealizująca pozwala na krytyczne rozróżnienie racji rzeczywistych od pozornych w odniesieniu do realnego świata.

${ }^{55}$ „Porozumienie zatem to zawsze porozumienie co do czegoś. Rozumieć się to porozumieć się co do czegoś” (H.-G. Gadamer, dz. cyt., s. 184).
} 
jako absolutną. Pozwalając uniknąć konfrontacji przez narzucanie słabszym rozwiązań strony silniejszej, dialog spełnia ważne zadanie humanizacji świata, m.in. przez ujawnienie wielorakich założeń kulturowych, społecznych, światopoglądowych, religijnych, filozoficznych i innych, sprawiających, że mimo używania tych samych słów, uczestnicy dialogu społecznego mówią w rzeczywistości innymi językami. Szczególne miejsce w sferze publicznej przypada założeniom w sferze aksjologicznej ${ }^{56}$, ponieważ to one decydują o tym, co uważa się za wartościowe i godne uwagi.

Dlatego mające nastąpić w rozmowie porozumienie co do danej sprawy oznacza w sposób konieczny, że dopiero w rozmowie zostanie wypracowany pewien wspólny język. Nie polega to na stosowaniu narzędzi od zewnątrz i nie można nawet powiedzieć, że to partnerzy dostosowują się do siebie; w udanej rozmowie poddają się obaj prawdzie rzeczy, która wiąże ich nowymi więzami wspólnoty. Porozumienie w rozmowie nie polega na samym tylko monologu i forsowaniu własnego stanowiska, lecz jest przemianą we wspólnotę, w której nie pozostaje się tym, czym się było ${ }^{57}$.

Ponieważ każdy dialog ma w sobie coś ze sztuki, nie wystarczy doskonalenie samych technik i form dialogowania, a tym bardziej manipulowania ${ }^{58}$ drugą stroną za pomocą znanych w literaturze różnego rodzaju chwytów erystycznych $^{59}$. Uczymy się dialogowania, uprawiając właśnie dialog.

12. Jakie wnioski z przedstawionych rozważań wypływają dla pedagogiki? Mimo wielu ważnych prac (także w Polsce), poświęconych roli dialogu $\mathrm{w}$ pedagogice ${ }^{60}$, nie dostrzegliśmy, by pojęcie dialogu w pedagogice ${ }^{61}$ doczekało się tu bardziej systematycznego opracowania. Istniejące prace odwołują się najczęściej do filozoficznych analiz kategorii dialogu ${ }^{62}$, rzadziej próbują ją charakteryzować na własną rękę, co gorsza, poprzestając niekiedy na zdroworozsądkowych, skądinąd słusznych, lecz teoretycznie niepogłębionych apelach, np. by wychowawca (nauczyciel) zajmował w stosunku do

${ }^{56}$ J. Mizińska zwraca szczególną uwagę na milczące, aksjologiczne tło dialogu, na to, z jakiego świata wartości wychodzą partnerzy dialogu, bo przesądza ono o jego skuteczności.

${ }^{57}$ H.-G. Gadamer, dz. cyt., s. 351.

${ }^{58}$ M. Tokarz, Argumentacja. Perswazja. Manipulacja. Wyktady z teorii komunikacji, Gdańsk 2006; R. B. Cialdini, Wywieranie wptywu na ludzi. Teoria i praktyka, Gdańsk 2009.

${ }^{59}$ A. Schoppenhauer, Erystyka czyli sztuka prowadzenia sporów, Kraków 1976.

${ }^{60}$ Prace takie publikuje np., ukazujący się od 1985, miesięcznik „Edukacja i Dialog”, który określa się jako czasopismo liderów edukacji.

${ }^{61} \mathrm{~W}$ odnośnej literaturze spotykamy, obok terminu «dialog pedagogiczny», niemal synonimicznie terminy: «dialog wychowawczy», «dialog edukacyjny» i «dialog dydaktyczny».

${ }^{62}$ Por. np. J. Gara, Pedagogiczne implikacje filozofii dialogu, Kraków 2008. 
wychowanka (ucznia) postawę otwartą oraz ,akceptował go takim, jakim jest". My również siłą rzeczy zadawalamy się ogólnymi konstatacjami.

Zauważmy zatem, że rozumienie dialogu w pedagogice uzależnione jest od tego, jak pojmie się samą pedagogikę i odpowiednio strategie wychowawczo-edukacyjne. Odróżnijmy prowizorycznie pedagogikę autorytarną (pedagogikę przymusu), gdzie wychowawca występuje z pozycji ostatecznego autorytetu, domagającego się bezwzględnego posłuchu ze strony wychowanka oraz pedagogikę permisywną (jak antypedagogika), uważająca każdy rodzaj przymusu za szkodliwy dla wychowanka. U podstaw każdej z nich leży inna koncepcja człowieka. W pierwszym przypadku traktuje się wychowanka jako podmiot, który zasadniczo nie jest w stanie trafnie sam osądzić, co jest dla niego dobre, $w$ drugim pojawia się obraz wychowanka jako podmiotu zdolnego w każdym przypadku do samodzielnego decydowania o tym, co dla niego najlepsze. Miejsce pedagogiki, nazwijmy ją roboczo „pedagogiką dialogu", byłoby pośrodku: w jej ujęciu wychowanek to bardziej lub mniej równorzędny (czasem? zawsze?) partner, który w dialogu z wychowawcą wspólnie podejmuje decyzje w istotnych dla siebie sprawach ${ }^{63}$.

Chociaż trudno podać satysfakcjonującą definicję dialogu, nie wydaje się słuszna taka uniwersalizacja terminu dialog, by każdy rodzaj kontaktu słownego a nawet pozawerbalnego między wychowawcą i wychowankiem nazywać dialogiem, ponieważ groziłoby to znaczeniowym jego rozmyciem. O tym, że w procesie wychowywania należy rozmawiać, wiedziano zawsze. Ale dialog wychowawczy jest czymś więcej. Polega nie tylko na rozmawianiu o sprawach ważnych dla wychowanka, lecz na dopuszczeniu sytuacji, kiedy może on powiedzieć „nie” i to „nie” zostanie zaakceptowane.

Dialog w pedagogice obejmuje zresztą nie tylko wychowawcę i wychowanka, lecz na różnych szczeblach wszystkich uczestników procesu wychowawczo-edukacyjnego: państwo i religie (Kościoły), instytucje państwowe i prywatne, odpowiedzialne za wychowanie, rodziców i opiekunów prawnych wychowanka oraz - nie na ostatnim miejscu - samych teoretyków pedagogiki, usiłujących się porozumieć między sobą co do najbardziej celowych i skutecznych strategii wychowywania.

Pojęcie dialogu pojawia się w pedagogice $\mathrm{w}$ dwu co najmniej kontekstach: jako sposób wychowywania poprzez dialog oraz jako zadanie wychowywania do umiejętności dialogu. W obu przypadkach powinien przenikać cały proces wychowawczy i wszystkie działania edukacyjne, a nie być sporadycznie tylko stosowanym zabiegiem. Zauważmy ogólnie, że dialog w pedagogice - m.in. ze względu na swą funkcjonalną użyteczność - jest dość

${ }^{63}$ Por. przykładowo, H. Romanowska-Łakomy, Partnerski dialog jako forma wychowania, „Zagadnienia Wychowawcze a Zdrowie Psychiczne” 2-5 (1985), s. 5-20. 
powszechnie uważany za wartość ${ }^{64}$. W aspekcie społeczno-psychologicznym służy likwidowaniu napięcia między wychowawcą a wychowankiem, między wychowankami między sobą, między wychowankami a społeczeństwem itp. W ten sposób przyczynia się do łagodzenia konfliktów i likwidowania potencjalnej agresji, narastającej u tego, kto nie ma możliwości wyrażenia swych poglądów i samodzielnego decydowania o swym zachowaniu. W swej funkcji komunikacyjnej dialog ułatwia porozumienie między wychowawcą a wychowankami, a także wychowanków pomiędzy sobą itp., przez zrozumienie racji teoretycznych lub praktycznych, leżących u podstaw wyboru lub odrzucenia pewnego postępowania wychowawczego. Podobnie w swej funkcji poznawczej dialog uchodzi za ważne źródło wiedzy pedagogicznej co do wyboru właściwej strategii wychowawczej. Rozmawiając z wychowankiem, wychowawca dowiaduje się nie tylko o jego potrzebach, możliwościach i właściwych motywach zachowania, lecz również o sobie samym i swoich sposobach (zaletach i wadach) postępowania (informacja zwrotna). Uzyskana w ten sposób wiedza ma oczywiste, istotne znaczenie dla praktyki wychowawczej, służąc odróżnieniu prawdy od fałszu, kiedy staje się źródłem pewności poznawczej. Nowa i często niespodziewana prawda, która wyłania się w dialogu wychowawczym, nie ma charakteru tylko epistemicznego (wiedzy ogólnej lub szczegółowej), lecz - co ważniejsze wymiar egzystencjalny. Jak to ujmują filozofowie dialogu: każda rozmowa odznacza się jakąś mistyczną niemal uchwytnością drugiego człowieka. Dlatego w swej funkcji egzystencjalnej, personalistycznej i aksjologicznej dialog, co podkreśla szczególnie mocno filozofia spotkania, staje się miejscem doświadczania drugiego człowieka jako źródła prawdy o nas samych oraz sposobem identyfikacji i ubogacenia własnego JA.

W pedagogice chodzi o coś więcej niż instrumentalne ${ }^{65}$ tylko wykorzystywanie dialogu w praktyce wychowawczej dla jego doraźnych ,owoców”, ponieważ samo dialogowanie jest wartością, np. ze względu na rozwój nie-ego (allo) centrycznej, prospołecznej osobowości wychowanka, przygotowywanego do przejęcia w przyszłości odpowiedzialności za innych. W przeciwieństwie do monologu w wychowywaniu i nauczaniu, który hamuje naturalną dociekliwość i krytycyzm dziecka ${ }^{66}$, dialog odpowiada jego spontanicznej potrzebie poznawczej, gdyż od początku stawia ono pytania

\footnotetext{
${ }^{64} \mathrm{Na}$ niezbędną obecność dialogu w wychowaniu zwraca szczególną uwagę antypedagogika.

${ }^{65}$ Dialog pedagogiczny może przybrać postać wysublimowanej manipulacji, kiedy np. prowadzony jest $\mathrm{z}$ intencją wykorzystania uzyskanej wiedzy do własnych celów, rozbieżnych $\mathrm{z}$ interesami partnera.

${ }^{66}$ M. Śnieżyński, Dialog edukacyjny, Kraków 2001; tenże, Sztuka dialogu. Teoretyczne założenia a szkolna rzeczywistość, Kraków 2005.
} 
pod adresem otaczającej rzeczywistości i oczekuje odpowiedzi. Dlatego pedagogika nie tylko korzysta $\mathrm{z}$ dialogu jako formy wychowywania, lecz chce wychowywać do dialogu, uważając $\mathrm{z}$ wielu powodów opanowanie umiejętności dialogicznych za szczególnie ważne w sytuacji powstawania społeczeństw globalnych i pluralistycznych. Jeżeli najogólniej pojąć wychowanie jako wdrażanie w świat wartości z intencją zmiany jego sposobów widzenia, a w rezultacie przybranie przez wychowanka nowych postaw wobec siebie i innych ludzi, dialog jest formą wprowadzania w świat wartości, tworzenia i podtrzymywania wspólnoty międzyludzkiej oraz w sytuacji europejskiej metodą przygotowywania do życia w społeczeństwach demokratycznych ${ }^{67}$.

Dialog z jednej strony zakłada równorzędność jego partnerów, z drugiej zmierza do uchylenia istniejących między nimi różnic. $Z$ jednej strony, postuluje $\operatorname{sie}^{68}$, by wychowawca traktował wychowanka jako partnera w dialogu wychowawczym, respektując jego indywidualność (niepowtarzalność) i godność jako osoby. $Z$ drugiej strony, proponowane przez pedagogów modele idealnego dialogu, w postaci np. postulatu bezwarunkowej akceptacji drugiej osoby taka, jaką jest, znajdują w małej, niestety, mierze zastosowanie w konkretnej sytuacji wychowawczej i mogą rodzić frustracje wychowawców nie dorastających do niego. Ale trudno przecież tak po prostu zakładać, by w dialogu pedagogicznym mogła mieć miejsce całkowita równość stron ${ }^{69}$, by racje jego uczestników były rzeczywiście równie ważne i by mógł się on obejść całkowicie bez nacisku i narzucania swej woli ze strony wychowawcy ${ }^{70}$. Ktoś właśnie dlatego zostaje (mianowany) wychowawca, że powinien być mądrzejszy i emocjonalnie dojrzalszy. Różnice dotyczą przykładowo wieku, doświadczenia, wiedzy, zależności instytucjonalnej, a przede wszystkim odpowiedzialności wychowawcy wobec społeczeństwa, rodziców i oddelegowującej go instytucji. Wychowawcy stawia się przecież np. zadanie, by aspołeczne zachowania wychowanka zamienił na prospo-

${ }^{67}$ Tenże, Sztuka ...

${ }^{68}$ Tenże, Dialog...

${ }^{69}$ Przykładowo, M. Buber uważa relację wychowawczą za asymetryczną ze względu na dominującą rolę wychowawcy. Wychowawca, mistrz i przewodnik, „doświadcza tego, jak jest wychowywany uczeń, lecz uczeń nie doświadcza tego, jak wychowuje nauczyciel. Wychowawca znajduje się na dwóch końcach tej samej sytuacji, uczeń tylko na jednym. W momencie, kiedy uczeń zdolny jest doświadczyć jej z drugiej strony, stosunek wychowawczy ginie albo przemienia się w przyjaźń”. M. Buber, Wychowanie, „Znak” 4 (1968), s. 442-461.

${ }^{70} \mathrm{~J}$. Rutkowiak mówi w tym kontekście nawet o „dialogu bez arbitra”. J. Rutkowiak, „Dialog bez arbitra” - jako koncepcja relacji między nauczycielem a uczniem, „Ruch Pedagogiczny" 5-6 (1984), s. 38-49. Odsyłamy do pracy zbiorowej pod redakcją J. Rutkowiak, Pytanie, dialog, wychowanie, Warszawa 1992. Por. również R. Kwaśnica, Ku dialogowi w pedagogice, w: B. Śliwerski (red.), Pedagogika alternatywna. Dylematy teorii, t. 1, Łódź, Kraków 1995, s. 79-91. 
łeczne. Czyżby więc dialog pedagogiczny musiał się kończyć niekiedy autorytarnym, instytucjonalnie i prawnie usankcjonowanym przymusem, $\mathrm{tj}$. przysłowiowym „odebraniem dziecku zapałek”? Ale można sobie również wyobrazić wychowanie, które będzie umiejętnym łączeniem strategii autorytetu i dialogu. Zawsze przecież pozostaje możliwość, że nawet wkraczając od czasu do czasu autorytarnie, wychowawca wyjaśni i usprawiedliwi w rozmowie z wychowankiem swe poczynania, próbując go przekonać do swych racji i poczynań. Aktualny problem obecności symboli religijnych w szkole pokazuje, że tylko dialog społeczny może przybliżyć jego w miarę bezkonfliktowe rozwiązanie.

Na przykładzie dialogu pedagogicznego okazuje się raz jeszcze, że jest on sztuka, wymagającą pewnego talentu (uzdolnienia) ze strony wychowawcy, a nie samego opanowania (erystycznych) technik dialogu ${ }^{71}$. Dlatego jego wynik pozostaje nieprzewidywalny dla obu stron dialogu wychowawczego. Nie należy, naturalnie, sądzić naiwnie, że za jego pomocą da się rozwiązać wszystkie problemy wychowawcze, bo chociaż niezbędny, nie załatwia wszystkiego. Między innymi dlatego, że o udanym dialogu, prowadzącym (niekiedy) do wypracowania wspólnego stanowiska, decyduje szereg czynników zewnętrznych, jak środowisko wychowawcze, przychylne podejmowaniu dialogu lub mu wrogie, przyjmowane przez daną społeczność normy społeczne, wzorce kulturowe i systemy wartości (pielęgnowane np. przez społeczeństwa demokratyczne), jak również nie mniej istotne osobowe predyspozycje wychowawcy. Dodatkowo światopoglądowe osadzenie pedagogiki sprawia, że każda jej postać wiąże się z określoną (filozoficzną, religijną) wizją człowieka, która również wywiera wpływ na teorię i praktykę wychowawczą ${ }^{72}$.

\section{Dialogue as the way to the truth about man (Summary)}

The article discusses thoroughly some problems connected with the use of dialogue in the educational sciences. We analyze the history of the concept of dialogue, its different notions and definitions, its synonyms and antonyms, its

\footnotetext{
${ }^{71}$ Uzdolnieniami i osobowymi predyspozycjami nauczyciela i wychowawcy zajmuje się m.in. pedeutologia. Por. H. Kwiatkowska, Pedeutologia, Warszawa 2008.

72 Por. E. Ryczan, Pojęcie dialogu w pedagogice, rozprawa magisterska napisana i obroniona w 2004 r. na Seminarium z Teoretycznych Podstaw Pedagogiki w Instytucie Pedagogiki KUL (promotor A. Bronk); A. Małdrzykowska, Implikacje pedagogiczne filozofii dialogu Martina Bubera, rozprawa magisterska napisana i obroniona w 2009 r. na Seminarium z Teoretycznych Podstaw Pedagogiki w Instytucie Pedagogiki KUL (promotor A. Bronk).
} 
dialectical structure, functions, conditions and the crucial problem of its truthfulness and intersubjectivity when used as an instrument of cognition. Most of all we are interested in the multiplex relation between the dialogue and the truth especially when dialogue is seen as privileged way to the knowledge of man. We notice that in the educational studies the notion of dialogue is generally treated as a positive value. It has here two principal meanings: as a specific method of education, i.e. teaching and learning through dialogue, and as an objective of education to foster the skills and habit of dialogue, necessary in any democratic society and community. Exploiting possibly ample contemporary literature, we pay a special attention to two traditions of dialogue: the philosophical hermeneutics of Hans-Georg Gadamer and philosophy of dialogue (M. Buber, F. Rosenzweig). We conclude that even though the notion of dialogue has in educational sciences an imprecise meaning it is used here broadly not only for a theoretical characterizations of education but as a tool in many educational strategies. 